\title{
51. Arapça nahiv çalışmaları önemli nahiv ekolleri ve nahiv öğretimi
}

\section{Mehmet BÖLÜKBAŞI ${ }^{1}$}

APA: Bölükbaşı, M. (2021). Arapça nahiv çalışmaları önemli nahiv ekolleri ve nahiv öğretimi. RumeliDE Dil ve Edebiyat Araştırmaları Dergisi, (24), 926-935. DOI: 10.2900o/rumelide.990703.

$\ddot{\mathbf{O} z}$

Köklü bir dil olan Arapça, İslamiyet geldikten sonra büyük bir ilerleme kaydetmiştir. Bununla birlikte; Arapça öğretimi ilk başlarda, ticarî ve dinî nedenlerle ortaya çıkmış daha sonra İslam dinini yaymak için yapılan fetih hareketleri neticesinde yeni coğrafyalar ve farklı kültürlerle karşılaşılmıştır. Fethedilen yerlerde, Arapça öğrenmek isteyen topluluklara Arapçayı öğretmek amaciyla Arapçada gramer çalışmalarına ihtiyaç duyulmuş ve bu sayede Arap gramerinin temelleri atılmıştır. Bu durumun sonucunda Arap gramerinin ilk eserleri telif edilmiş ayrıca Arap diline yeni lehçeler girmeye başlamıştır. Arap dilinin önemli gramer kaynakları telif edilmiş ve önemli gramerciler ortaya çıkmıştır. İslamiyet’i kabul eden diğer milletlere mensup kişilerin Kur’ân-ı Kerîm’i yanlış okumalarını önlemek amacıyla Kur’ân-ı Kerîm harekelenmiştir. Bu sayede yanlış okumaların önüne geçilmiştir. Sâmi dil ailesinden olan Arapça; Eski, Klasik, Orta, Modern Arapça ve sürekli gelişen mahalli lehçeler olmak üzere sınıflandırılmıştır. Bu bağlamda, Arapça geniş bir coğrafyaya yayıldığı ve Müslümanlığı kabul eden farklı milletler tarafından konuşulduğu için dinamik bir dil olma özelliğini sürdürmektedir. Batı dünyasında ise ilk başlarda; Hıristiyanlar Müslümanlarla yapacakları dini tartışmalarda üstün gelebilmek amacıyla Arapça öğrenmişlerdir. Daha sonra Arapça öğrenimi ticarî ve kültürel faaliyetler nedeniyle son yıllarda artış göstermiştir. Bu çalışmada, dünyada dört yüz milyon kişi tarafından konuşulan ve bir buçuk milyar Müslümanın ibadet dili ile kadim dillerden olan Arapçanın tarihsel gelişimi, öğretim tarihçesi nahiv çalışmaları, önemli nahiv ekolleri ve nahiv öğretimi hakkında bilgiler verilmiştir.

Anahtar kelimeler: Gramer çalışmaları, Arapça öğretimi, Nahiv ekolleri, Arapça, Arapçanın tarihsel gelişimi

\section{Arabic grammar studies important grammar schools and grammar teaching}

\begin{abstract}
Arabic, a long-established language, has made great progress after Islam. However; Arabic teaching appeared at first, for commercial and religious reasons, and then new geographies and different cultures were encountered as a result of the conquest movements to spread the religion of Islam. In conquered places, grammar studies in Arabic were needed to teach Arabic to communities who want to learn Arabic, thereby laying the foundations of Arab grammar. As a result of this situation, the first works of the Arabic grammar were copyrighted and new dialects started to be introduced into the Arabic language. Important grammatical sources of the Arabic language have been copyrighted and important grammarists have emerged. The Quran was putting dot over letter in order to prevent people from other nations who accept Islam from reading the Qur'an wrongly. In this way, false readings are prevented. Arabic, a member of the Sami language family; It is classified as Old, Classic,
\end{abstract}

Dr. Öğr. Üyesi, Bartın Üniversitesi, Edebiyat Fakültesi, Mütercim Tercümanlık Bölümü, Arapça Mütercim Tercümanlık ABD (Bartın, Türkiye), blkbamehmet@gmail.com, ORCID ID: oooo-0002-5923-3920 [Araştırma makalesi, Makale kayıt tarihi: 13.07.2021-kabul tarihi: 20.09.2021; DOI: 10.29000/rumelide.990703]

Adres | Address

RumeliDE Dil ve Edebiyat Araştırmalar Dergisi $\quad$ RumeliDE Journal of Language and Literature Studies

Osmanağa Mahallesi, Mürver Çiçeği Sokak, No:14/8 $\quad$ Osmanağa Mahallesi, Mürver Çiçeği Sokak, No:14/8

Kadıköy - ISTANBUL / TÜRKIYE 34714 Kadıköy - ISTANBUL / TURKEY 34714

e-posta: editor@rumelide.com e-mail: editor@rumelide.com,

tel: +90 505 7958124, +90 2167730616 phone: +90 505 7958124, +90 2167730616 
Middle, Modern Arabic and continuously developing local dialects. In this context, Arabic continues to be a dynamic language as it spreads to a wide geography and is spoken by different nations that accept Islam. In the Western world, at first; Christians learned Arabic in order to prevail in their religious discussions with Muslims. Later, Arabic education has increased in recent years due to commercial and cultural activities. In this study, information is given about the historical development and teaching history of Arabic, syntax studies, important schools of syntax and teaching of grammar which is spoken by four hundred million people and is the language of worship of one and a half billion Muslims.

Keywords: Grammar studies, Arabic teaching, Nahiv schools, Arabic, Historical development of Arabic

\section{Giriş}

Sâmi dil ailesinden ve kadim dillerden biri olan Arapça gramer yapısı ve barındırdığı sözcük sayısının çeşitliliği sayesinde zengin bir dil olarak kabul edilmektedir. Sâmi dillerinden sayılmasının nedeni ise; Arapça ve İbranice kaynak eserlerde Hz. Nuh'un oğlu Sam'dan geldiğinden belirtilmiş olmasından kaynaklanmaktadır. Arapça dil yapısını Kur'ân-ı Kerîm sayesinde koruyabilmiştir. Bu sayede günümüzde etkinliği devam etmektedir. Arapçanın ilk yazılı kaynakları MÖ VIII. ve MS VI. asırda Seba, Kateban ve Hadramut kitabelerinde bulunmuştur. Bu kitabeler Klasik Arapça olarak adlandırılmıştır. İslamiyet'ten önce Arapça Arabistan'ın kuzeyinde Adnanî, güneyinde ise; Kahtanî olarak adlandırılan iki esas koldan oluşmaktaydı. Kuzey Arapçası Adnanî, Tihame, Necid, Hicaz ile Mekke'de konuşulan Enmar, Mudar ve Kureyş lehçelerini kapsamaktaydı. Güney Arapçası ise; Kahtanî, Himyeri, Gassani ve Kinde lehçelerinden meydana gelmekteydi (el-İskenderi, 1927: 48). İslamiyet'ten önce Mekke'de ticareti ve sosyal hayatı elinde bulunduran Kureyş kabilesinin şehirdeki etkinliği sayesinde zenginlik ve refah seviyesinin artışı neticesinde Arapça ön plana çıkmıştır. Bununla birlikte, Arapçaya ait esas kaynaklar M. VI. yüzyılda Cahiliye şiiri, Hz. Muhammed ile Halifeler döneminde yazılmış mektuplar, yapılan antlaşmalar ile Fasih Arapçanın özelliklerini barındıran Kur'ân-ı Kerîm'den oluşmaktadır (Kaddur, 2009: 59).

\section{Yöntem}

Nitel araştırma yapılırken veriler gözlem yapma, görüşme gerçekleştirme ve doküman edinme olmak üzere üç yolla toplanır (Kıral, 2020: 170). Tarihi süreçte, klasik ve modern olarak adlandırılan dönemlerde Arapça öğretiminde müfredat olarak kullanılmış olan Arap gramer kitapları doküman analizi tekniğiyle incelenmiştir. Arapça öğretiminin tarihsel gelişimi hakkında bilgiler derlenmiştir. Bu bilgiler ışığında Arap gramerinin ortaya çıkışı ve gelişim evreleri neden-sonuç bağlamında ele alınmıştır.

\section{Araştırmanın amacı ve önemi}

Araştırmanın amacı, İslamiyet öncesi gelişme gösteren ve İslamiyet geldikten sonra gerçekleşen fetih hareketleri neticesinde belli başlı kaideleri oluşan Arapça öğretimi ve gramerinin tarihi süreçteki gelişimine ışı tutmak ve önemli Arapça gramer kitapları hakkında bilgiler vermektir. En yaygın olarak bilinen nahiv kitapları ele alınmıştır.

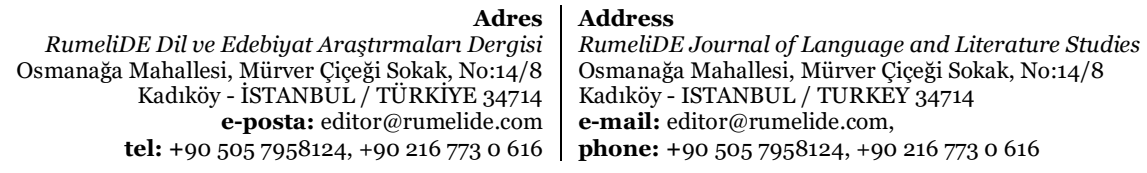




\section{Arapçanın tarihsel gelişimi}

Arapça, İslamiyet gelmeden yüz elli sene önce gelişimini edebi ve belagat yönünden tamamlamıştı. Kur'ân-ı Kerîm'in inmesiyle Arapça, Kur'ân hadis ve İslamî ilimlerde gelişme göstermeye başladı ve bu sayede Fasih Arapça ve Arapçanın temelleri korunarak günümüze kadar gelmeyi başardı. Arapça öncelikle Fasih Arapçayı, eski lehçeleri ve daha sonraki dönemlerde ortaya çıkan yerel lehçeleri (ammiceleri) kapsamaktadır (Zeydan, 1978, I: 89).

Arap dili öncelikle Klasik Arapça ve ona bağlı olan lehçeleri içermektedir. Arapçanın tarihsel gelişimi şöyle açılkanabilir.

Eski Arapça: Eski Arapçaya ait bilgilere eski kitabeler ile Araplarla iletişime geçmiş milletlerin metinlerinde yer alan kabile şahıs ve yer adlarında rastlanmaktadır (Hüseyin, 1960: 105).

Klasik Arapça: Klasik Arapça ve ona kaynak olan eski edebî lehçeler (VI.-VII. yy.) hakkındaki bilgilere eski edebi metinler, Kur'ân-ı Kerîm ve hadisler sayesinde ayrıca Arapçanın konuşulduğu coğrafyalarda telif edilmiş edebi çalışmalarda ve ona kaynak olan eski edebî lehçeler sayesinde ulaşmaktayız. Bu bağlamda Klasik Arapça VI. ve VII yüzyllarda etkin olan ve İslamiyet’ten önce konuşulan, edebi çalışmaların olduğu dönem ile günümüzü kapsamaktadır. Klasik Arapçanın temelini Kureyş lehçesi oluşturmaktadır. Bu bağlamda, diğer Arap lehçelerinden almış olduğu kelimeleri kendi bünyesinde sentezleyerek sözcük sarf ve nahiv bakımından zengin bir lehçe haline gelmiştir. Ayrıca Klasik Arapça İslami Arapça olarak kabul edilmektedir (Doğan, 2011: 75).

Orta Arapça: Orta Arapça üzerinde, İslam dininin halen devam eden bir etkisi bulunmaktadır. Fasih Arapça olarak kabul edilen Orta Arapçanın temelini ve esaslarını Kur'an'ı Kerim oluşturmaktadır. İslamiyet'in diğer milletler tarafından kabul edilmesi ve fetih hareketleri sayesinde yeni kültürlerle karşılaşılması neticesinde Arapça farklı milletler tarafından konuşulmaya başlanmıştır. Bu bağlamda Orta Arapça olarak adlandırılan yeni bir dil ortaya çıkmış ve bu dil ilim, sanat ve edebiyat faaliyetleri sonucu gelişme göstermiştir. Daha sonraları ise bu dil Arap Yarımadasının dışına çıkarak İslam dininin kabul edildiği bölgelerde ilim, sanat, din ve medeniyet dili haline gelmiştir (Afîfî, 1980: 127).

Modern Arapça: 1798 yılında Napolyon'un Mısır’ ele geçirmesi ile ortaya çıkmış bir kavramdır. Öncelikle Mısır'da başlayan Avrupa etkisi, daha sonra zaman içerisinde diğer Arap ülkelerinde görülmeye başlanmıştır. Bu bağlamda, batı dillerinden Arapçaya bilim, teknik ve sanat alanlarıyla ilgili birçok yeni kelime girmiştir. Arapçayı, batı dillerinin etkisinden korumak amacıyla dil akademileri kurularak Arapçaya giren yabancı kelimelere Arapça karşılıklar bulunarak sözlüklere kaydedilmiştir. Modern Arapça olarak kabul edilen yabancı kelimelere Arapça karşlık bulma faaliyeti günümüzde de devam etmektedir. Modern Arapça Arap ülkelerinin ortak basın ve yayım dili olarak kabul edilmiştir (eş-Şihâbî, 1965: 153).

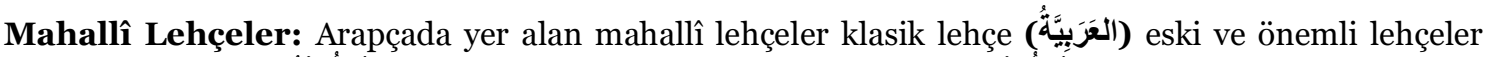

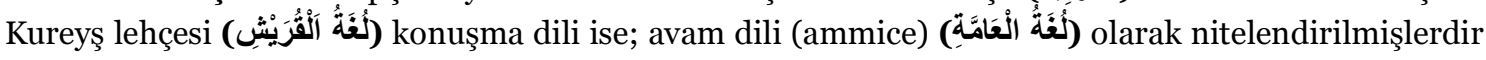
(el-Halvacî,1978: 93). Lehçe, dilin ucu ve sözün tınısı anlamına gelmektedir (el-Ferâhîdî,1988, III: 163). Fetihler neticesinde Arapların diğer milletlerle karşılaşması ve birlikte yaşamaya başlaması neticesinde dil ve kültür etkileşimi gerçekleşmiştir. Bu etkileşim nedeniyle Arapçada konuşma dilinde çok farklı lehçeler ve kelime telaffuzları ortaya çıkmıştır. Bu bağlamda, gırtlak yapıları bazı Arapça kelimeleri telaffuz etmeye uygun olmayan milletler kendi girtlaklarına göre sözcükleri telaffuz etmeye

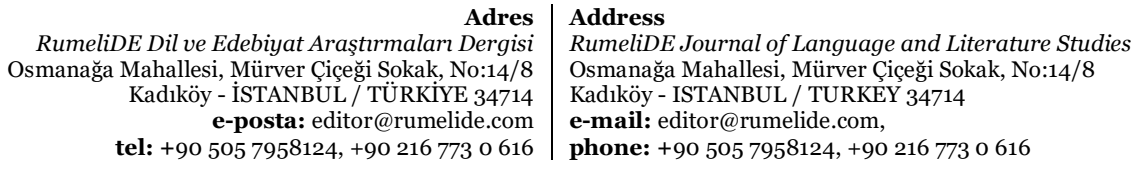


başlamışlardır. Geniş bir coğrafyaya yayılan ve yabancı milletler tarafından konuşulan Arapçanın belli bir dönem sonra orijinal yapısında bazı değişikliler meydana gelmiştir. Bu değişiklikler Arapçada farklı lehçelerin ortaya çıkmasına neden olmuştur. Bu bağlamda lehçeler, bölgeden bölgeye hatta mahalleden mahalleye değişme göstermektedir. Bu değişim harekede, sözcüğün telaffuzunda yapısında ve anlamında görülmektedir. Bununla birlikte, Arap lehçeleri gelişmeye devam etmektedirler (Enîs, 1989: 73).

\section{Arapça nahiv çalışmalarının ve ekollerinin ortaya çıkışı}

İlk Arapça Nahiv (gramer) çalışmaları, Kur'ân-ı Kerîm'in okunurken yanlış telaffuz edilmesini engellemek ve doğru anlaşılması amacıyla Ebu'l-Esved ed-Dueli (ö.688) tarafindan Kur'ân-ı Kerîm'in harekelenmesi ile başlamıştır. Bu ilk nahiv çalışması yeterli olmamış bu durum üzerine nahiv kaidelerini belirlemek için Ali b. Ebu Talib (ö.661) Ebu'l-Esved ed-Dueli'yi görevlendirmiştir. Bu sayede Arapçanın ilk nahiv kuralları tespit edilmiş ve bunlar nahiv olarak adlandırılmıştır (el-Afğani, 1978:69). Arapça nahiv alanında çalışmalar yapmış olan ilk kişi Abdullah b. Ebi İshâk’tır. (ö.745). Daha sonra İsâ b. Ömer es-Sekâfî (ö.766) el-Câmi ve el-íkmâl (el-Mukmil) adlı iki eser telif etmiştir. Bu eserler daha çok kendisinden önce nahiv ile uğraşan kişilerin çalışmalarını bir araya getirip düzenlemesi şeklinde olmuştur. Bir diğer önemli nahivci olan Halil b. Ahmed el-Ferâhîdî (ö.791) Kitâbu'l-Ayn adlı sözlüğü telif etmiştir. Bu eser Arap dünyasında alfabetik dizin uygulanarak lugat alanında telif edilmiş oldukça önemli bir eserdir. Halil b. Ahmed el-Ferâhîdı̂’nin öğrencisi Sîbeveyh (ö.796) telif ettiği el-Kitâb adlı eserinde Arapça gramer kuralları ile dilin anlamı hakkında bilgiler vermiştir (es-Suyûtî, 1975: 47).

Arap dilinin kuruluşu ve gramer çalışmalarının derlenmesi amacıyla önce Basra'da kurulan Basra Dil okulunda dil çalışmaları yapılmıştır. Basra'da dil alanında yapılan çalışmalar neticesinde daha sonra Kûfe'de dil okulu kurulmuştur. Bu ekoller Arap dilinin kurallarını belli bir düzene bağlamıştır. Ekoller Arap dilinin gelişmesine büyük katkı sağlamıştır. Bu iki ekolde yetişen ünlü dilciler günümüze kadar ulaşan önemli nahiv eserleri telif etmişlerdir. Önceleri Kur'ân-ı Kerîm’in yanlış okunmasını engellemek amacıyla ortaya çıkan nahiv çalışmaları daha sonra kurulan Basra ve Kûfe dil okullarında yetişen ve aynı hocalardan ders alan dilcilerin Arap grameri hakkında farklı görüşlere sahip olmaları neticesinde Arap grameri ilerleme kaydetmiştir. Bu iki ekolde yetişen dilciler Arap grameri ile ilgili önemli kaynak eserler telif etmişlerdir. Basra ve Kûfe dil ekollerinin Arap dili grameri alanında yapmış olduğu çalışmalar sayesinde daha sonra Bağdat, Endülüs ve Mısır'da dil ekolleri ortaya çıkmıştır ve bu ekollerde Arap gramerinin gelişmesinde önemli rol oynamışlardır (Bakırcı \& Demirayak, 2001: 17).

\section{Basra dil ekolü ve önemli temsilcileri}

Arap dünyasında nahiv çalışmalarının Basra'da başlamasının birkaç sebebi bulunmaktadır. Öncelikle Fasih Arapça konuşan kabilelerden olan Kays ve Temîm kabileleri ile Basra'da ikamet eden birçok kabilenin Fasih Arapçayı kullanmış olmalarıdır. Bununla birlikte; Basra'da insanların alışveriş yaptıkları pazar yerinde ilmi ve edebi tartışmaların yapılması, ayrıca pazarda yapılan nahiv ve edebiyat ile ilgili fikirlerin nahivciler tarafından kayıt edilmesi gibi nedenlerden dolayı Basra'da nahivle ilgilenen âlimler Basra Dil Ekolünü kurma imkânı bulmuşlardır. Abbasiler döneminde Irak'ın Basra şehrinde kurulan Basra Dil Ekolü temsilcileri nahiv konularını seçerken titiz davranmış daha çok Fasih Arapça konuşan Kays, Temîm ve Esed kabilelerinden nakiller yapmışlardır (ez-Zubeydî, 1954: 121). Basra dil ekolünün en önemli temsilcileri Halil b. Ahmed el-Ferâhîdî (ö.791) öğrencisi Sîbeveyh’i (ö.796) Ahfeş el-Avsat (ö.826) Müberred (ö.900) ve Zeccâc (ö. 923) gibi nahivcilerden oluşmaktaydı. el-Ferâhîdî nahiv ve sarf ilminin kurallarını belirlemiştir. Bu bağlamda; Kitâbu'l-'Ayn adlı eseri telif etmiştir. Eser 'Ayn harfi ile

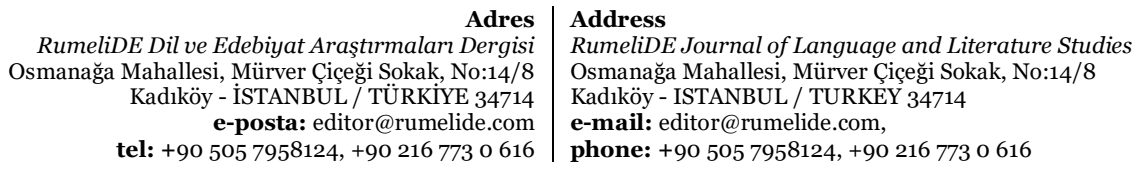


başladığı için Kitâbu'l-'Ayn olarak adlandırılmıştır. VIII. asırda Arap dilinde lugat alanında telif edilmiş zengin içeriğe sahip önemli bir kaynaktır. Ayrıca el-Ferâhîdî, eserini ilk defa alfabetik bir dizin içerisinde ve sözcüklerin köklerini meydana getiren sessizleri ele alarak telif etmiştir Ekolün bir diğer temsilcisi Sîbeveyh (ö. 796) telif ettiği el-Kitâb adlı eseriyle nahiv ilmine büyük katkısı olmuştur. Sîbeveyh eserde, sarf ve nahiv konuları teferruatlı bir şekilde ele almış ayrıca Arap dilinin anlam ve pratikte kullanımına da değinmiştir. Arap gramerinin kaidelerinin oluşmasında en önemli kaynak olarak Bedevîlerin günlük konuşmalarını esas almıştır (İbnu'n-Nedîm,1985, II: 179). Sîbeveyh, el-Kitâb adlı eserinde Arap dili ve edebiyatının esaslarını özgün bir anlatımla ele almıştır. Ayrıca, eser Arap gramerini kapsamlı şekilde anlatan önemli bir kaynaktır (Muhammed, 1999:9).

\section{Kûfe dil ekolü ve önemli temsilcileri}

Abbasiler döneminde Irak’ın Kûfe şehrinde kurulan Kûfe dil ekolü; er-Ruasi (ö.8o6), el-Kisai (ö.805) ve el-Ferra (ö. 822) gibi nahivcilerden oluşmaktaydı. Basra Dil Ekolünden etkilenmişlerdir. Fakat bazı nahiv konularında görüş ayrılıkları yaşamışlardır. Arap nahvini kuralları ve belli bir sisteme dayalı olan bir şekle getirmek ayrıca nahiv ile ilgisi olmayan konuları ayıklamak gayesiyle çalışmalar yapmışlardır. Kûfe Dil Ekolü Basra Dil Ekolü ile ortak çalışmalar yapmış daha sonra ise her iki ekol arasında nahiv terimleri ve konularının adlandırılması ve tanımlanması gibi ortaya çıan tartışmaların ileri dereceye varması ve anlaşmazlıkların artması neticesi ekoller faaliyetlerine son vermiştir. Bu ekollerin yerine Bağdat Dil ekolü ortaya çımıştır (et-Tantâvî, 1991: 97).

\section{Bağdat dil ekolü ve önemli temsilcileri}

Bu ekolün en önemli temsilcileri Ebû Alî el-Fârisî (ö.987), İbn Cinnî (ö. 1002) ve Zemahşerî (ö. 1143) gibi önemli nahivcilerdi. Bu ekol Basra ve Kûfe dil ekollerinin nahiv alanında ortaya koydukları çalışmaları harmanlayarak kendi ekollerine ait görüşler meydana getirmişlerdir. Bu bağlamda Ebû Alî el-Fârisî, el-İzâh, et-Tekmile, el-Hucce fí 'ileli'l-kurâa adlı eserleri telif etmiştir. İbn Cinnî 'el-Hesâis' adlı eserinde nahivle ilgili terimleri açlklamıştır. Bir diğer önemli nahivci Zemahşerî ise; el-Mufassal adlı eserini Araplara, Arapçayı öğretmek amacıyla telif ettiğini belirterek nahiv alanında önemli bir eser ortaya koymuştur. Bağdat dil ekolü nahiv alanında önemli çalışmalar ve eserler bırakmıştır (el-Afğânî, 1978: 65).

\section{Endülüs dil ekolü ve önemli temsilcileri}

Araplar Endülüs'ü fetih ettikten sonra burada Arapça öğretmeye başlamışlardır. Endülüs dil ekolü temsilcilerinin önceleri nahiv konusunda kendilerine ait fikirleri olmadığından Kûfe dil ekolünün nahiv konusundaki görüşlerini esas alarak çalışmalar yapmışlardır. Belli bir birikime ulaştıktan sonra Endülüs nahivcileri çalışmalarında kendi görüşlerini ortaya koyarak nahiv alanında önemli çalışmalar yapmışlardır. Endülüs ekolü İbn Madâ' (ö. 1196) İbn 'Usfûr (ö.1270) ve İbn Mâlik (ö.1274) gibi nahivcilerden oluşmaktaydı. Bu bağlamda İbn Madâ' telif ettiği er-Red 'alâ'n-nuhât adlı eserinde nahiv ilmine farklı bir bakış açısı getirmeye çalışmıştır. Eserinde, Arap grameri öğretilirken aşırı derecede teferruata girildiğini bu yüzden Arapça öğrenmek isteyenlerin zorlandığını ifade etmiştir. Ayrıntılı gramer anlatımının öğrenmeyi olumsuz etkilediğini ve anlatımın yalın ve anlaşlır olmasının daha faydalı olacağını belirtmiştir (Sertâvî, 1988: 91).

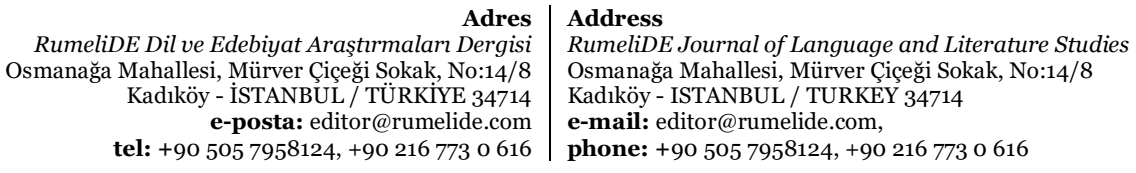


İbn Mâlik, el-Elfiyye adlı eserinde nahiv konularının kolay bir şekilde öğrenilmesi amacıyla anlaşılır ve akıcı bir üslup kullanmıştır. Nahvin ayrıntılı bir şekilde ele alınmadığı küçük hacimli olan eser uzun yıllar boyunca ders kitabı olarak okutulmuş ve esere birçok şerh yazılmıştır (Zehebî, 1981: 183).

\section{Mısır dil ekolü ve önemli temsilcileri}

Mısır Dil Ekolünün temsilcileri İbnu'l-Hâcib (ö. 1249) İbn Hişâm (ö. 1360) ve Suyûtî (ö. 1505) gibi nahivcilerdir. Basra ve Kûfe dil ekollerinin izinden gitmişlerdir. Bu iki ekolün yazdığı eserleri açıklama yoluna gitmişlerdir. Bununla birlikte, ekolün temsilcileri nahiv ilmine dair faydalı eserlerde telif etmişlerdir. Bu bağlamda; İbnu'l-Hâcib, el-Kâfiye adlı eserinde nahivle ilgili konuları ayrıntıya girmeden daha anlaşılır bir şekilde ele almıştır. Üç esas kısımdan oluşan eserde öncelikle isimler daha sonra fiiller ve son olarak harfler anlatılmış ve bu esas bölümlerin altında nahiv bilgileri veren alt kısımlar bulunmaktadır (Dayf,1968, s. 89). İbn Hişâm Muġni’l-lebîb adlı eserinde nahiv konularını edat, şibhü’l-cümle, cümle şeklinde tek tek ele almıştır. Nahiv ilmine büyük katkısı olmuştur (Ziriklî, 1955: 181).

\section{Arap gramerinin öğretimi için yapılan çalışmalar}

Arap Gramerini öğretmek amacıyla öncelikle ayrıntılı ve cilt sayısı birden fazla olan nahiv kitapları telif edilmiştir. Teferruatlı nahiv kitaplarının Arapça öğretiminde istenilen seviyede faydalı olmadığı görülmesi üzerine daha az sayfadan oluşan gramer konularını ayrıntıya girmeden anlatan eserler yazılmıştır. Bu bağlamda; Nahiv konularını özet şeklinde anlatan kitaplar arasında el-Halef el-Ahmer'in (ö.797) 'el-Mukaddime fi'n-nahv', Ahfeş el-Evsat'n (ö.831) el-Evsat fi'n-nahv, Ali b. Hamza el-Kisai'nin (ö. 825) el-Muhtasar fi’n Nahv ile Ebu Ca’fer en Nehhas'in et-Tuffaha, Zeccacî’nin (ö. 949) el-Cumel gibi eserler bulunmaktadır (Hicâzî, 1968:147).

Bu bağlamda; Arapça gramerinin anlaşılması için yapılan çalışmalar belli bir seviyenin üzerine çıamamıştır. Çünkü gramer konularını özet şeklinde anlatan eserler nahiv konularına yeni bir bakış açısı getirmemiş ve anlaşılabilir bir teknik kullanılmadan telif edilmişlerdir. Bununla birlikte, nahiv alanında yazılmış eserler daha çok gramer konularının belirlenmesi ve kayda geçirilmesi şeklinde olmuştur. Konular açıklanırken yorum yapılmamış, karışık ve anlaşılmayan durumlar ile ilgili açıklamalara yer verilmemiştir. Bu durum gramer konularının anlaşılmasını zorlaştırmıştır.

Nahiv alanında telif edilen eserlerden biri olan Sîbeveyh'in (ö.796) el-Kitâb adlı eserinde tam olarak oturmamış bir sistem içerisinde gramer konuları ayrıntılı şekilde anlatılmış ayrıca gramer ile ilgili olmayan konuların ayıklanmamış olması gibi hususlar nedeniyle eser, Arapça öğretimine uygun olmadığı için eleştirilmiştir. Sîbeveyh ile aynı dönemde yaşamış olan Halef el-Ahmer (ö.796) Mukaddime fi'n-nahv adlı eserinde Sîbeveyh'in el-Kitâb adlı eserinin gramer öğretimi için fazla ayrıntılı olduğunu ayrıca gramer ile ilgili olmayan konularında ele alındığını bu durumun kitabın anlaşılmasını zorlaştırdığını belirtmiştir. Bu sebeplerden ötürü; Arapça bilmeyen kişilerin eserden Arapça öğrenmelerinin mümkün olmadığını ifade etmiştir. Bununla birlikte; Arapça öğretiminde özellikle gramer kitaplarında konuların kısa anlaşılır ve iç içe girmeden ve anlaşılır bir sistemle anlatılması gerektiğini vurgulamıştır. Halef el-Ahmer (ö.796) Muḳaddime fi’n-naḩv adlı eserini Arapça gramer alanında telif edilen kitapların Arapça öğretimine uygun olmadığını ve eksikliği gidermek için telif ettiğini belirtmiştir (el-Ahmer, 1961: 125).

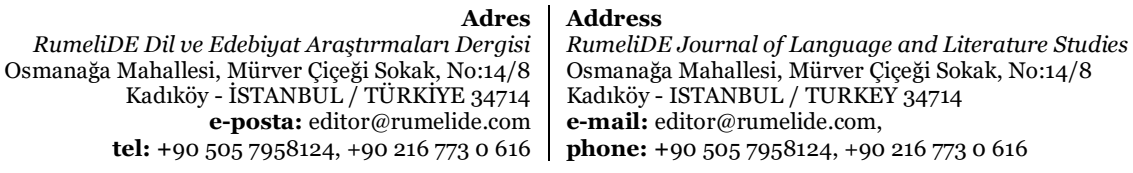


İbn Madâ' ise; nahiv ile ilgili telif ettiği 'er-Red 'alâ’n-nuhât' isimli eserinde nahivcilerin Arap gramerini zorlaştırarak anlaşılmasını imkânsız hale getirdiklerini ayrıca nahiv konularını gereksiz ayrıntılarla açıklamaya çalıştıklarını belirtmiştir. Bununla birlikte; nahivcilerin anlatımının abartılı oluşuna vurgu yapmış ve gramer konuları ile ilgili olmayan bilgilere de değindiklerini ifade etmiştir. Bu nedenlerden ötürü telif edilen eserlerin Arapça bilmeyen kişilere Arapçayı öğretmede yetersiz kaldığını vurgulamıştır (Abbâs, 1960: 93).

\section{Arap gramerinde yenilikçi faaliyetler}

Arap gramerinde yenilikçi faaliyetlere katkısı olan nahivcilerden biriside Şevki Dayftır (ö.2005). Dayf'a göre, Nahiv konularının gereksiz ayrıntılardan arındırılması ve içeriklerinin anlaşılır bir şekilde belli bir sistematik içerisinde anlatılması gerekir ancak bu sayede Arapça öğrenmek isteyenlerin nahiv konularını ve Arapçayı öğrenebileceklerini belirtmiştir. Bu bağlamda Şevki Dayf, nahiv konularını anlaşılır ve ayrıntıya girmeden ele aldığı en-Nahvu'l-cedîd adlı eserini yazmıştır. Dayf, nahvin işlevsel olması gerektiğini, gramer konularının gereksiz ayrıntılardan arındırılması gerektiğini belirtmiştir (Dayf, 1966: 79).

Emin el-Hûlî (ö. 1966) Arap eğitim sisteminde 12 sene boyunca Arapça eğitimi verildiğini fakat öğrencilerin Arapça gramerini öğrenemediklerini belirtmiştir. Bu olumsuz durumu ortadan kaldırmak için nahiv konularının sadeleştirilmesi gerektiğini ayrıca Arapça i’rab konularının ayrıntılı işlenmemesi gerektiğini ancak bu sayede Arapça öğreniminde başarı elde edilmesinin mümkün olacağını ifade etmiştir (Hasan, 1970: 65)

Ahmed Hasan ez-Zeyyât (ö. 1968) ise; gramer konularının gerekli olduğunu fakat Arapça eğitiminin günlük hayattan kopuk olduğunu sadece belli konularda yazılmış metinler üzerinden derslerin işlendiğini bu durumun Arapça öğrenimini olumsuz etkilediğini belirtmiştir. Bu bağlamda; ez-Zeyyât Arapça öğretim tekniklerinin yenilenmesi ve günümüz şartlarına uyarlanması gerektiğini ifade etmiştir (el-Azzâvî,1982: 129).

Gramer konularının daha anlaşılır olabilmesi için, doğru konuşma ve yazma becerilerinin geliştirilmesi gerekir. Doğru konuşma gramer konularının eksiksiz öğrenilmesine, yazma ise; gramer kurallarını akılda kalıcı kılmada önemli katkı sağlamaktadır. Dolayısıyla, konuşma ve yazma; gramer öğreniminde göz ardı edilmemesi gereken iki temel unsurdur (et-Tahtâvî,1870: 171).

Arap grameri karmaşık bir yapıya sahip olduğundan, gramer öğretiminin basitten karmaşığa doğru öğretilmesi ve aşırı ayrıntıya girilmemesi gerekir. Gramer öğretimi öğrencilerin derse katılımını teşvik etmelidir. Dinleme, konuşma, kendini Arapça ifade etme, okuma ve yazma gibi etkinliklerle öğrencilerin derse katılımı sağlanmalıdır. Belirtilen hususlar göz önüne alınarak modern dilciler gramer öğretimine fayda sağlamayan konuların çıkarılması gerektiğini belirtmiş̧lerdir (Dolunay, 2010: 275).

Modern dilciler Arapça gramerinde yer alan mefûlu ma'ah, tenâzu ve iştiğal gibi konuların çıkarılmasını veya sadece ayrıntıya girmeden öğretilmesi gerektiğini vurgulamışlardır (el-Bâr, 2009: 64). Ayrıca kural bakımından oldukça karışık olan bazı Arapça gramer konularının örneklerle açıklanmasının yeterli olduğunu ifade etmişlerdir. Örneğin; Modern dilcilerden biri olan Şevki Dayf (ö.2005) Arap gramerinde yer alan kırık çoğul/cemi mükesser konusunun kurallarının karmaşık olduğunu ve bu kuralın dilde çoğu kimse tarafından tam olarak bilinmediğini bu konunun sadece örnek verilerek ayrıntıya girmeden öğretilmesi gerektiğini dile getirmiştir (Dayf, 2013: 97).

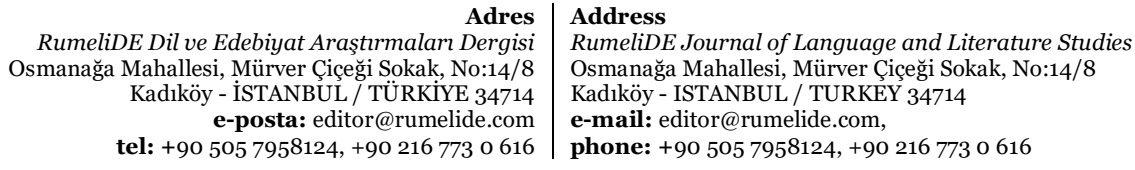


Gramer kurallarını bilmek, dil öğrenimi için oldukça önemlidir. Ancak, gramer sadece konuların ezberlenmesinden ibaret olmamalıdır. Gramer konularının kalıcı olarak öğretilmesi için okuma, yazma, dinleme ve konuşma becerilerinin de öğretilmesi gerekir (İbn Haldûn,2004: II, 385).

\section{Modern yöntemlerle telif edilmiş gramer kitapları}

Belli başlı gelişim aşamalarından geçen Arapça Nahiv çalışmaları Modern Çağ’da yeni ve anlaşılması kolay olan kitapların yazılması ile sonuçlanmıştır. Nahiv eserleri artık hacimli ve teferruatlı olmak yerine daha anlaşılır ve sade olmaya başlamıştır. Bu bağlamda Modern Yöntemlerle telif edilen ilk eser Rifầa et- Tahtâvî (ö.1873) tarafından telif edilen et-Tuhfetu'l-mektebiyye fí takrîbi'l-luğati'l-'Arabiyye isimli nahiv kitabıdır. Eserde gramer konuları anlatılırken Fransızca gramer kitapları örnek alınmıştır. Konular basit, anlaşılır ve kısa tabirler ile anlatılmıştır. Bununla birlikte kitapta açıklamalı tablolar ve uygulamalı örnekler verilmiş̧tir (et-Tahtâvî,1870: 99).

Hıfnî Nâsif (ö. 1919) lise öğrencilerinin Arapça öğrenmeleri için telif ettiği Kavâidu'l-luğat’il-'Arabiyye adlı eserinde nahiv konularını basitleştirip sadeleştirerek anlatmıştır (Halefullah, 1961: 89). Ali el-Cârim (ö.1949) ve Mustafa Emîn'in birlikte telif ettikleri en-Nahvu'l-vadih fì kavâidi’l luğati'l-'Arabiyye adlı eserde nahiv konularını mümkün olan en basit ve anlaşılır seviyede anlatmaya çalışmışlardır. Fakat Klasik nahiv konularını kitabın içerisinde değinmişlerdir. Bir anlamda klasik yöntemle modern yöntemi sentezlemeye çalışmışlardır (Harb,1986: 87).

Arap grameri ile ilgili çalışmalar günümüzde de devam etmektedir yapılan çalışmalar olumlu sonuçlar vermiştir. Günümüzde Arapça eğitimi görsel ve işitsel materyallerin kullanılması ve internetin kullanımı ile en üst seviyeye çıkmıştır. Teknolojik gelişmeler sayesinde Arapça eğitim kitapları dijital ortamda dünyanın her yerine ulaşabilmekte ve bu sayede Arapça öğretimi büyük ivme kazanmaktadır.

\section{Tartışma}

Klasik kitaplarla modern kitapların öğretiminde karşılaşılan zorluklarla ilgili sistematik çalışmalar yapılmalıdır. Modern Arapça eğitim ve öğretiminde eski medreselerdeki yerini koruyamayan klasik nahiv kitapları yeni bir bakış açısıyla değerlendirilerek ele alınabilmelidir. Modern kitapların telifinde klasik kitapların müelliflerinin eserlerinde izledikleri yol ve yöntemler dikkate alındığı takdirde eskinin tecrübesiyle yeni bilgi ve tekniklerin birleştirilmesi daha verimli eserlerin ortaya çımasını sağlayacaktır. Arapça öğreniminde Dilbilgisinin önemi yadsınamaz bir gerçektir. Ancak Arapça öğretilirken gereğinden fazla gramer bilgisinin verilmesi öğrenimi olumsuz etkileyebilmektedir. Yeteri kadar aşırı ayrıntıya girilmeden Modern Arapça öğretim yöntemlerinden yararlanılarak Arap gramerinin öğretilmesi gerekir. Ayrıca gramer konuları içerisinde yer alan ibarelerin ve fiillerin cümle içerisinde kullanılarak öğretilmesi Arapça öğretimine büyük katkısı olacaktır. Çünkü, teorik olan bilgilerin pratik olarak cümle içerisinde kullanılması Arapça öğretiminin daha faydalı ve etkin şekilde öğretilmesine ve istenilen düzeyde bir eğitimin gerçekleşmesinde önemli bir etken olacağı aşikardır.

\section{Sonuç}

Kur'ân-ı Kerîm’in doğru okunması amacıyla başlamış olan Arap grameri çalışmaları daha sonra gerçekleşen fetihler neticesinde farklı milletlerle iletişime geçilmesiyle devam etmiştir. Bu bağlamda; ortaya çıan iletişim sayesinde İslamiyet'i kabul eden milletler Arapça konuşurken telaffuz hataları yapmaya başlamışlardır. Bu hataları düzeltmek ve Arapçayı diğer dillerin olumsuz etkilerinden korumak için gramer çalışmalarına başlayan Arap nahivcileri, öncelikle gramer kurallarını derleyip hacimli

\footnotetext{
\begin{tabular}{r|l} 
Adres & Address \\
RumeliDE Dil ve Edebiyat Araştırmaları Dergisi & RumeliDE Journal of Language and Literature Studies
\end{tabular}

Osmanağa Mahallesi, Mürver Çiçeği Sokkak, No:14/8 $\quad$ Osmanağa Mahallesi, Mürver Çiçeği Sokak, No:14/8

Kadıköy - ÍSTANBUL / TÜRKIYE 34714 Kadıköy - ISTANBUL / TURKEY 34714

e-posta: editor@rumelide.com e-mail: editor@rumelide.com,

tel: +90 505 7958124, +90 2167730616 phone: +90 505 7958124, +90 2167730616
} 
eserler telif etmeye başlamışlardır. Fakat bu eserleri telif eden müellifler belli bir sisteme ve disipline bağlı olmadan elde ettikleri gramer materyallerini yorumlamadan kaydetmişlerdir. Eserlerdeki bilgiler sistematik olarak yazılmamış olmalarına rağmen bu çalışmalar sonucu ortaya çıkan bilgi birikimi sayesinde dil ekolleri kurulmuş ve bu ekoller nahiv alanında önemli eserler telif etmişlerdir. Ekoller sayesinde nahiv alanındaki ilk çalışmalarda elde edilen birikim neticesinde daha sonraki gramer kitapları öncekilere göre sade ve anlaşılır bir şekilde telif edilmişlerdir. Bu bağlamda, uzun müddet nahiv alanında devam eden çalışmalar sonucu Arap grameri çağın gereksinimlerine göre gelişimini sürdürmektedir.

\section{Kaynakça}

Abbâs, İ. (1960). Târîhu'l-edebi'l-Endelusî. Beyrut.

Afîfî, F. (1980). Neşe ve tețavvuru'l-kitâbeti'l-hațțiyyetil-Arabiyye ve devrihe's-s_ekāfi ve'l-ictimâ î. Kuveyt.

Bakırcl, S., Demirayak, K. (2001). Arap Dili Grameri Tarihi. Erzurum.

Dayf, Ş. (1966). Teysiru’n nahvi’t -ta'limi. Kahire: Dâru'l-Ma‘ârif.

Dayf, Ş. (1968). el-Medârisu'n-nahviyye. Kahire: Dâru'l-Ma'ârif.

Dayf, Ş. (2013). Tecdîdu'n-Naḥv. Kahire: Dâru'l-Ma‘ârif.

Doğan, C. (2011). Arapça Öğrenim ve Öğretim Klavuzu. İstanbul: Ensar Neşriyat.

Dolunay, S.K. (2010). Dil Bilgisi Öğretiminin Amacı ve Önemi”, Türklük Bilimi Araştırmaları Dergisi. s.27, 275-284

Enîs, F. (1989). el-Lehecât ve Üslûbu Dirâsetihâ. Beyrut.

el-Ahmer, H. (1961). Muḳaddime fïn-naḥv. (Nşr). İzzeddin et-Tenûhî. Dımaşk.

el-Bâr, 'Alâ Binti Yâsîn (2009). Teysîru'n-Nahvv Beyne'l-Cedvâ ve'l-Hurûc 'alâ Vâkịii'l- Lugia, Câmi'atu'lMelik Abdülaziz Kulliyyetu'l-Âdẩb ve'l-'Ulumi'li̇nsâniyye Ḳımu'l-Lugati'l-'Arabiyye. (Basılmamış Yüksek lisans tezi), Suudi Arabistan.

el-Afğânî, S. (1978). Min târihi”n-nahv. Beyrût: Dâru'l-Fikr.

el-Azzâvî, N. R. (1982). Aḥmed Ḥasan ez-Zeyyât kâtiben ve nâḳden. Bağdat.

el-Ferâhîdî, Ebu Abdurrahman Halîl b. Ahmed b. Amr (1988). Kitabu'l-Ayn. (Thk). Mehdi Mahzumi, İbrahim Samerrai, Beyrut: Muessesetu'l-A'lemi li'l-Matbuat. I-VIII.

el-Halvacî, A. (1978). el-Mahțuttâtu'l-Arabiyye. Riyad.

el-İskenderi, A. (1927). el-Vasif fi'l edebi'l Arabi ve tarihihi. Kahire.

es-Suyûtî, C. (1975). el-İktirâh fì ilmi ușûli’n-naḥv. (Nşr). Ahmet Subhi Furat, İstanbul.

eş-Şihâbî, M. (1965). el-Mușțalahâatu'l-ilmiyye fi'l-luġati'l-Arabiyye fi'l-ḳadîm ve'l-ḥadîs. Dımaşk.

et-Tahtâvî, R. (1870). et-Tuhfetu'l-Mektebiyye li takrîbi'l-luğati'l'Arabiyye. Kahire.

et-Tantâvî, M. (1991). Neş'etu'n-nahvi ve târihu eşheri’n-nuhât. Kahire: Dâru'l-Menâr.

ez-Zubeydî, Muhammed b. el-Hasan Ebû Bekr. (1954). Tabakâtu'n-nahviyyîn ve'l-luğâviyyîn. (Thk). Muhammed Ebu'l Fazl İbrâhim. Kahire.

Hasan, İ. (1970). el-Mektebetu'l-Arabiyye. Dımaşk.

Halefullah, A. M. (1961). Muhâạarât an Hifnî Nâșıf kâtiben ve bâḥis_en. Kahire.

Harb, G. (1986). Alî el-Cârim bâhịis_en ve edîben. Kahire.

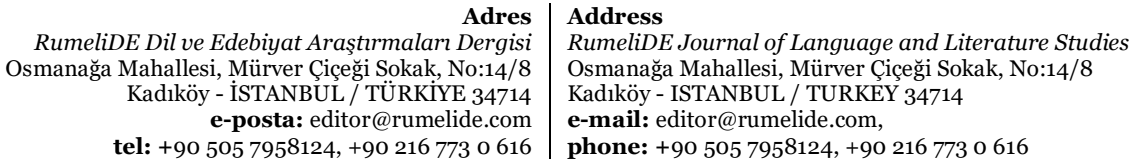


Hicâzî, M. (1968). el-Lugatu'l-Arabiyye. Kahire.

Hüseyin, M. H. (1960). Dirâsât fi'l-Arabiyye ve târîhihâ. Dımaşk.

İbn Haldûn, Abdurrahmân b. Muhammed (2004). Mukaddime. (Thk.) Abdullah Muhammed ed-Dervisş. Dımaşk: Dâru Ya'rub. I-II.

İbnu'n-Nedîm, Muhammed b. İshâk (1985). el-Fihrist. (Thk). Mustafâ eş-Şuveymî. Tunus. I- XIV.

Kıral, B. (2020). Nitel Bir Veri Analizi Yöntemi Olarak Doküman Analizi. Siirt Üniversitesi Sosyal Bilimler Enstitüsü Dergisi, sy:15, s.170-189.

Muhammed, A. S. (1999). el-Ușûlu'l-belâgizyye fi Kitâbi Sîbeveyhi ve eseruhâ fi'l-baḥs_ìl-belâgīi. Kahire.

Sertâvî, M. (1988). İbn Madâ' el-Kurtûbî ve cuhûduhu'n-nahviyye. Ürdün.

Zeydan, C. (1978). Tarihu'l edebi'l luğati'l Arabiyye. I-IV. Beyrut. Zehebî, Şemsuddîn Muhammed Ahmed b. Osmân (1981). Siyeru 'a lâmi’n-nubelâ. (Thk). Şu'ayb el-Arnavut-Alî Ebû Zeyd. Beyrut.

Ziriklî, H. (1955). el-'A'lâm kâmusu terâcimi li eşherïr-ricâl ve’n-nisâ mine'l-'Arabî ve’l-musta'rebîn ve'l-musteşrikîn. Kahire.

RumeliDE Dil ve Edebiyat Araştırmaları Dergisi Osmanağa Mahallesi, Mürver Çiçeği Sokak, No:14/8 Kadıköy - İSTANBUL / TÜRKIYE 34714 e-posta: editor@rumelide.com tel: +90 $5057958124,+902167730616$
Address

RumeliDE Journal of Language and Literature Studies Osmanağa Mahallesi, Mürver Çiçeği Sokak, No:14/8

Kadıköy - ISTANBUL / TURKEY 34714

e-mail: editor@rumelide.com,

phone: +90 $5057958124,+902167730616$ 